\title{
A Literature-Based Approach on International Perspectives of Bilingual Education
}

\author{
Burhan Ozfidan (Corresponding author) \\ Department of Teaching, Learning and Culture \\ Texas A\&M University, TX, USA \\ E-mail: b.ozfidan@tamu.edu \\ Lynn M. Burlbaw \\ Department of Teaching, Learning and Culture \\ Texas A\&M University, TX, USA \\ E-mail: burlbaw@tamu.edu
}

Received: July 15, 2016 Accepted: August 25, 2017 Published: September 1, 2017

doi:10.5296/jei.v3i2.11551 URL: https://doi.org/10.5296/jei.v3i2.11551 


\section{Abstract}

This study examines the bilingual education in Spain and in Canada, and discusses their historical backgrounds, current bilingual education programs in use, and teacher proficiency within their bilingual education programs. The purpose of this study is to examine these two countries' bilingual education programs and find a way to implement a bilingual education program in Turkey. Because of innovative legal conditions and the establishment of special programs in Basque Country in Spain, the potential for increasing learners and speakers of the language is greater than ever before. Bilingual education models in the BAC have increased the number of well-educated young students and allowed them to have a better future. French is taught as a foreign language in Canada, and English is usually accepted as a first language, which has hindered the development of diverse types of immersion programs. Immersion programs have helped students learn other subjects and have also allowed them to acquire an additional language. This study presents a comparison of the situation of minority languages in Turkey with Canada and Spain offers many lessons. The purpose of this discussion is to establish the benefits and shortcomings of these bilingual education programs and the suitability of their models for minority groups living in Turkey. To provide an efficient education system, the differing needs of various areas should be considered. This can be demonstrated in examples drawn from Canada's consideration of the French language and Spain's consideration of the Basque language.

Keywords: Basque, French, Turkish, Bilingual education

\section{Introduction}

Many nations of the world are multilingual by nature of their multicultural populations, e.g., India, China, Republic of South Africa, etc. Other nations, while having diverse populations, have a dominant culture and a primary language, e.g., the United States of America, Spain, Singapore, etc. How these two categories of nations address the issue of minority languages varies from co-existence to contentious discussions on how best to incorporate, or assimilate, the non-dominate groups linguistic and cultural heritage into the social fabric. While the adoption of cultural practices of, and by, both the dominant and non-dominant populations occurs symbiotically, the relationship between languages used and cultural maintenance if often contentious (Blanton, 2004; De La Trinidad, 2015; Everling, 2009; Gándara, 2015; Kim, Hutchison, \& Winsler, 2015; Peleato, 2013; San Miguel, 2004; Ozfidan \& Burlbaw, 2016). Two countries, however, and not without controversy at times, have developed working models to allow for language use and recognition of non-dominant cultures. These countries, Spain and the Basque community and Canada and the Francophone community largely found in Quebec, offer possible solutions to the issue of multilingual societies. After an examination of the models used in Spain and Canada, the authors suggest how these models might be translated into another country, Turkey, which has multiple non-dominant populations, which have their own, distinct languages.

The use of the Basque language has been officially allowed in zones in which the language has never been used before: elementary and secondary education, university, church, printed materials, media, and among others (Ozfidan \& Burlbaw, 2016). Currently, the Basque 
Autonomous Community has a very systematic ongoing bilingual education program. The sociological results of French immersion programs have also been found to have produced considerable progress in developing relationships and friendships between English-French speaking scholars, and "a strong feeling of assimilation" in the French-Canadian community (Ricento, 2013). This study examines the bilingual education in Spain and in Canada, and discusses their historical backgrounds, current bilingual education programs in use, and teacher proficiency within their bilingual education programs. The reason these two countries were chosen is their historical backgrounds and linguistic challenges are similar to minority groups in Turkey.

\section{Bilingual Education in Spain: The Case of Basque}

\subsection{Historical Background}

The community of Basque speakers is split into three political units: the Basque Autonomous Community, Navarre in Spain, and the Atlantic Pyrenees Department of France. The Basque Provinces of Spain are situated in northern Spain and are among the 17 semi-autonomous communities of Spain (Lasagabaster, 2001; CIA World Factbook, 2017). For many centuries, the Basque language has been spoken natively in this area, which is on the border with France, south of the Atlantic Pyrenees Department of France. Historically speaking, most Basques had had little contact with the written version of their language as the written version of Basque was not used in administration (Lasagabaster, 2001; see also Hualde, Lakarra, \& Trask, 1995).

Today, the Basque Autonomous Community (BAC) in Spain is comprised of three provinces, Alva, Biscay, and Gipuskoa, with approximately 2.5 million inhabitants (Lasagabaster, 2001). Donostia-San Sebastian, Bilbao, and Vitoria-Gasteiz are the largest cities of the Basque Country and the centers of the BAC (P. M. Horn-Marsh \& K. L. Horn-Marsh, 2009).

The Basque Nationalist Party, established in 1895, followed a policy of recovering and restoring the Basque language in Spain. Basque nationalists, according to Gardner (2000), have control over both the parliament and the government in the Basque Autonomous Community of northern Spain. However, to ensure that a stable government is realized, they have had to rely on alliances with other parties. The strength of each Basque party: Basque Solidarity (EA, EuskoAlkartasuna), Unity (HB, now Batasuna), Basque Left (EE, Euskadiko Ezkerra), and the Basque Nationalist Party (PNV/EAJ, Partido Nacionalista Vasco/Eusko Alderdi Jeltzalea), varies noticeably from province to province in Spain.

The use of the Basque language began to fall by the wayside as the result of several historical events. First, during the $18^{\text {th }}$ century, monarchies in France and Spain opposed the use of Basque. In 1716, the Spanish absolutist monarchy strengthened centralization and introduced Castilian as the official language of the country (affect the Basque population in 3 provinces in Spain). After the French Revolution of 1792, French became the only official language of the First Republic (affecting the people in what now is the Atlantic Pyrenees Department). In both cases using languages other than Castilian Spanish or French was officially forbidden (Lasagabaster, 2001). 
A second primary cause of the decline of the Basque language was a byproduct of industrialization in the $19^{\text {th }}$ century, which lead to the ever-growing urbanization of Basque speakers in the industrial provinces. One factor of this industrialization was an in-migration to Basque areas, which included large numbers of non-Basque speaking workers in the newly industrial towns, especially Bilbao, where Spanish-speaking investors and managers developed an iron and steel industry. Urbanization and in-migration meant that Basque speakers had to learn Spanish to survive (Gardner, 2000). This phenomenon caused the use of the Basque language to vanish almost completely from the public and economic arenas (Lasagabaster, 2001).

In 1918, efforts to preserve the Basque language led to the development of the Basque Language Academy and the Basque Studies Society (Gardner, 2000). The purpose of the language activities implemented by the academy was to increase the Basque language's social status, rather than planning standardization of the Basque linguistic structure (Urla, 2009). Nevertheless, until the late 1960s, the Basque language was not taught as a subject in the schools in the Basque Provinces.

However, all these efforts were disrupted in the aftermath of the Spanish Civil War (1936-1939), when all Basque territory in Spain came under the control of dictator Francisco Franco. One of the earliest measures "Franco took was to forbid the use of the Catalan and Basque languages, not only at school, but also in every single social sphere, and those who violated this were persecuted" (Etxeberria, 2006, p.127) For example, those "teachers who were members of nationalist parties were forced to give up their jobs, and those who sympathized with them were forcibly moved to other regions" (Etxeberria, 2006, p.128). These measures and in-migration had damaging impacts, and the number of Basque speakers fell from $83 \%$ of the population at the beginning of the $20^{\text {th }}$ century to only $23 \%$ a half century later. However, during the last decade (1965-1975) of Franco's rule this linguistic repression was somewhat lessened, as the regime was breaking down and was not as oppressive as before (Etxeberria, 2006; Zalbide \& Cenoz, 2008).

In the late 1960s, efforts were made to resuscitate the Basque language, and the Basque Language Academy created a standardized version of Basque called Batu, which melded eight dialects into a standardized version. This singular version now has official language status in Spain (Lasagabaster, 2001). Besides this, the academy also worked to develop the fundamental infrastructure for formal Basque education. Moreover, in the late 1960s and early 1970s, according to Haddican (2007), Basque Country education was secretly developed through a night school network; therefore, Basque education, in the beginning, was formed unofficially. These schools, which were known as Ikastola, began as a public service and later obtained legal status.

In 1975, after the death of Franco, bilingual education models were introduced during the reign of King Juan Carlos I. Many students attended Basque daycare centers, and most of them went on to school to pursue their education (Zuazo, 1995). In the BAC, mandatory education involved six years of elementary education for children who were from age 6 to 12 and four years of secondary school for children who were from age 12 to 16 and (Sierra, 
2008). Currently, this bilingual education program remains successful in incorporating the preservation of the Basque culture and language in the face of the mainstream Spanish language (Valadez, Etxeberria, \& Intxausti, 2015).

\subsection{Bilingual Teaching Models in Spain}

To meet the rising requests from parents, the Basque language was offered in public education beginning in 1975 (Intxausti, Etxeberria, \& Joaristi, 2013). Since then educational language models in Basque have increasingly developed in all pre-university levels throughout Basque country. Breton and Ruiz (2008) noted that Basque language teaching in different models was proposed and added to public education in 1975. Based on the educational policy of the political party in power, the teaching Basque language was either promoted or benignly ignored but eventually was introduced throughout the whole community at all educational levels. Both private and public centers used the Basque language in pre-university teaching, which gave students the freedom to learn the Basque language. The Basque language officially started to be used in public and governmental places such as schools in 1976. From then on, the number of the Basque speakers and learners rapidly increased, and Basque language gained legal status in Spain in 1978. Both Basque and Spanish developed as mandatory focuses in entire educational institutions.

Bilingual education in the Basque County is divided into three models, which are Model A, Model B, and Model D (Zalbide \& Cenoz, 2008). In Model A, almost all topics are taught in Spanish, and Basque is taught as a second language for four to six hours in a week. This approach aims to assist students in comprehending the Basque language, in building stronger affirmative attitudes towards the Basque culture but not linguistic fluency. This model has limited success and use because more academic emphasis is placed on courses taught in Spanish (Gardner, 2000; Arzamendi \& Genesee, 1997).

In Model B, people who want to learn both Spanish and Basque are taught in the Basque language. The main goal in this model, according to Gardner (2000), is to reach fluency in the Basque language. The limitation of this model is that students cannot communicate fluently in schools because they have not learned Basque adequately; therefore, they do not prefer model B (Zalbide \& Cenoz, 2008; Gardner, 2000).

In Model D (no letter "C" exists in Basque), according to Gardner (2000), almost all subjects are taught in Spanish, and Basque is taught as an instructional language for five to six hours a week. This model aims for fluency in both Basque and Spanish. The limitation of the model is the lack of qualified teachers (Gardner, 2000; Zuazo, 1995; Lasagabaster, 2001; Etxeberria, 2006).

Today, a generation of native Basque speakers is a completely new phenomenon that has been accompanied by a wave of printed materials and people well-educated and literate in the Basque language. The government has printed many books in the Basque language yearly (Gardner, 2000; Zalbide \& Cenoz, 2008). Currently, using Basque (bilingually) in the elementary and secondary education, in published and written materials, and in public areas (such as church) has continued to develop. This situation of peaceful coexistence was arrived 
at after a period of unrest, which included bombings and assassinations.

\subsection{Materials for Teaching}

The introduction of Basque mainly for literature and language into teaching created the need for curriculum development on an extensive official basis (Gardner, 2000). Furthermore, the government immediately required essential materials in Basque to teach all topics. Subjects such as history and geography that had specific Basque-centered components were integrated into the curriculum. In incorporating bilingual education, the government has become more supportive and has increasingly improved its finance mechanisms for Basque-centered education (Zalbide \& Cenoz, 2008; Gardner, 2000). The Spanish central government, in Madrid, has completely funded the public schools, and supported and funded the private Ikastola schools, which had been funded completely parents in the later part of the Franco regime, have been supported and financed by the central government. Both governmental and private school students were provided teaching materials and funded by the Basque Government (Gardner, 2000).

\subsection{Teachers' Proficiency}

The main challenge for the educational system in the BAC has been the lack of teachers with the required ability and competence in Basque (Gardner, 2000). Teachers must get a proficiency diploma to be qualified. However, without acquiring this proficiency via a formal diploma, many teachers taught the medium of Basque in schools (Cenoz, 2008). Likewise, because of the language instruction in the 1980s, teachers whose native language was Basque only used Basque verbally; therefore, Spanish students had many difficulties (Cenoz, 2008). Hence, special courses have been organized to strengthen the grammar and vocabulary of Basque teachers and to increase their literacy level.

The Minister of Education in the BAC has organized in-service training through the Teacher Literacy and Second Language Learning (IRALE) program, which offers the possibility of entire or limited release from teaching responsibilities (Zalbide \&Cenoz, 2008). Participation is available every year. In the program, participants can become full-time students for a period of up to three years at particular universities in the IRALE program. In this case, teachers receive their full salary (Cenoz, 2012). To speed up teacher training, the IRALE program also included teachers who were on part-time courses during the school year or on full-time courses during the summer holidays (Zalbide \& Cenoz, 2008). At the end of three years, each teacher who has attended and successfully passed each part of this program receives a certificate of proficiency in both Basque and Spanish (Cenoz, 2012).

\subsection{Summary}

Because of innovative legal conditions and the establishment of special programs in Basque Country, the potential for increasing learners and speakers of the language is greater than ever before. Bilingual education models in the BAC have increased the number of well-educated young students and allowed them to have a better future. The use of the Basque language has been officially allowed in zones in which the language has never been used before: elementary and secondary education, university, church, printed materials, media, and among 
others. Currently, the Basque Autonomous Community has a very systematic ongoing bilingual education program (Valadez, Etxeberria, \& Intxausti, 2015).

\section{Bilingual Education in Canada: The Case of French Immersion}

The social and political development of Canada has had a strong connection with its neighbor the United States. Since the colonial period, the French and English, and later the Americans, have had extremely dramatic influences on what is known today as Canada (Mady, 2013; Laborda, 1997). In Canada, according to Laborda (1997), people use English for English-speaking groups, national business, overseas' visitors, and communicating with foreigners. However, French is commonly used in Quebec, in everyday informal situations, and in community relations. Therefore, bilingualism was necessary in particular regions in Canada. To provide an international perspective on bilingual education, the purpose of this section is to analyze and describe the prevalence of bilingual education in French Canada.

\subsection{Historical Background of Bilingual Education in Canada}

As bilingualism can be seen in the European colonization of Canada, it is not a unique notion in Canadian politics (Mady, 2013). Distinct European groups of people, particularly English and French, colonized the Canadian territories (Ricento, 2013). Powerful colonies that stood alongside pre-existing aboriginal communities in Canada, according to Hermans-Nymark (2013), were constructed by England and France. In the central and the eastern parts of Canada, the British founded and inhabited a province on the eastern seaboard, now Newfoundland, while the French colonies flourished and settled provinces in what is now Nova Scotia, New Brunswick, Quebec, and Prince Edward Island; all provinces located in the eastern part of Canada (Cooke, 2009). Colonial groups were geographically clustered mostly by cultural ethnicities (Ricento, 2013).

Many French and English speaking colonists were found in Canada by the early 1700s (Mady, 2014). The French colonists pursued their own legal routines, including civil law, usually spoke French, and practiced Catholicism. Civil Law is a body of law that can be referred to in each individual circumstance and was passed by parliament (Ricento, 2013). It is found in continental Europe and among is the oldest and most commonly surviving legal systems in the world. On the other hand, based on the common-law tradition, the British colonists followed a different legal system and generally spoke English and practiced Protestantism. The British Common Law system is one in which the law continually develops via judicial decisions in addition to being amended by laws passed by the legislature (CROP, 2006). In short, there were obvious differences between these two ethnicities in Canada.

During the early $18^{\text {th }}$ century, the British strengthened their power over the Canadian provinces. Thanks to a series of European wars (i.e., the Seven Years' War and Queen Anne's War), the British acquired many French colonies from eastern Canada in Quebec and the Maritimes (Roy, 2008). These new provinces were linguistically and culturally French-dominated while being politically dominated by the British; however, those who lived in these new provinces primarily spoke French and French religious and legal practices generally characterized their populations (Mady, 2012). 
Because of the history of colonialism, the federal government has followed a policy for language mainly based on a common bilingual community vision, described by the advancement of both French and English in all Canadian provinces (Government of Canada, 2003). Thus, the duality of linguistics is an essential aspect of the Canadian heritage. The language politics in Canada especially in Quebec, which is the core region of French Canada, are fierce (Mady, 2013; Ricento, 2013). In fact, developing a common bilingual community was not a main purpose of French-speaking Canada; instead, two different linguistic populations were envisioned, one centered in Quebec and the other inhabiting the rest of Canada.

These visions of the two populations have been mirrored frequently in the language policy of Quebec's Government (Government of Canada, 2003). The population of French-speaking Canada wanted French to be respected across the country, and they appreciated the work that the Canadian Government in Quebec was making to ensure the survival of the French culture and language all over Canada (Roy \& Galiev, 2011). The local governments of Quebec have followed language-related strategies to develop the French language as opposed to English since the1930s. These strategies have been aimed at establishing Quebec as the center of the French language and community in Canada. Thus, the government in Quebec has promoted the development of a uniquely French community within the region (Ricento, 2013). Quebec had attempted several referenda to establish independence and sovereigntyand separateness from English-speaking Canada; the two attempts failed because of political unrest (Mady, 2013).

In 2000, the Program for International Student Assessment (PISA), a worldwide study in member and non-member nations of school children's scholastic performance, affirmed that French Immersion in the Canadian School System followed a model of bilingual education utilized around the world, and was one of the most well-funded programs in the world. Parisot and Rinfret (2012) noted that French immersion began in Quebec in the 1960s due to political and parental pressures, and French immersion grew and bilingualism increased by approximately 25\% among young and adult Canadians aged 18-29. In Quebec, the first French immersion course began in 1965, and the program reached out to each of the nine other provinces. From then on, French immersion in all provinces in Canada has become available (Roy, 2008). All provinces in Canada offer voluntary programs for children who cannot speak French, so they are taught in French to encourage bilingualism.

Both French and English are the official languages throughout most Canadian provinces, although many parts of the country are not officially bilingual (Laborda, 1997). The English language is used for outsiders, national business, in discussions and dialogues with foreign visitors, and within the English-speaking community in Canada. In Quebec, however, French is used in all aspects of social life and in politics. Laborda (1997) stated, "French is widely used in the provincial government, in community relations, in everyday informal situations - such as jeux d'esprit (Riddles and Jokes) and laughing" (p. 1046). In the large cities, particularly in Quebec's largest city, Montreal, and among the educated classes, bilingualism is essential, but all other French-speaking provinces mostly use French. 


\subsection{Challenges Facing Canada's Bilingual Model}

In the 1960s, parents were not satisfied with their children's education in language because Anglophone students (a Canadian citizen whose first language was English) used the old fashioned audio-lingual method that was not aiding or improving their communicative abilities in the French language (Alberta Department of Education, 1992; Laborda, 1997); therefore, a new program was designed. Laborda said that the new program, French Immersion, was created.

To insist on the students understanding and appreciation of French Canadians without detracting from English Canadian culture; to provide the participating children with functional competence in both written and spoken French; to ensure achievement in academic subjects to commensurate with students' academic ability and grade level; and to promote and maintain normal levels of English language development (Laborda, 1997, p. 1047).

The new model mentioned covered both the second language and language learning curriculum needs for all students. In view of the new program, teaching methods changed significantly (CCL, 2007). Students obtained a vital amount of language information they could understand, and this was used to teach them a new language in the Canadian Gradual Immersion Program. Students were not pushed to learn and speak very soon, but rather in the natural stage of their individual development. In answering questions, students have been permitted to speak their mother tongue, particularly in the first stages, called early total immersion. All language skills comprising writing, reading, speaking, and listening skills are considered (Lambert \& Tucker, 1976). Activity begins with reading, and second grade students can read materials written in the French language. Gradually, English takes over as the language used for the most vital parts of instruction.

The Canadian Council on Learning (CCL) (2007) asserted that French immersion is a successful program; however, present French-immersion participation rates of $10 \%$ show that education via French immersion to enhance substantial French-English bilingualism among Canadians is not adequately extensive. Statistically, CCL also asserts that French immersion experienced a rapid increase during the 1980s and then was stagnant during the 1990s. Because less than $10 \%$ of French-immersion's eligible students registered in programs nationwide in 2006, the decision was made to increase French immersion over the next six years (CCL, 2007).

\subsection{French Immersion Programs}

Currently, in all ten Canadian provinces, French Immersion programs are available. Initially, classes for French Immersion in Quebec opened in 1965, and they extended to the other nine provinces in Canada. The Canadian government provides these programs for non-native children in French, and participation is voluntary. To encourage bilingualism, the children are taught in French (Parisot \& Rinfret, 2012). The major aim of these programs is to develop bilingualism in Canada (PISA, 2000). French Immersion also assists in the development of the appreciation and extension of the French culture. Because no differences exist in the 
curriculum, students will learn the same curricular content even if they are not registered in the French Immersion program. The only distinction is the language of instruction, and this distinction was intended to provide many affirmative results for students (McEachern, 2002).

\subsection{Types of Immersion Programs}

French immersion programs in the Canadian bilingual education system are divided into three models: Early French Immersion, Middle French Immersion, and Late French Immersion (McEachern, 2002).

\subsubsection{Early French Immersion}

Within these three models, Early French Immersion is generally considered to be the most efficient model because specialists who can speak both French and English teach the courses, and all instructions are in French except for English Language Arts at the elementary level (beginning in Grade 3) (Peirce\& And, 1993; Cummins, 1982; Taylor, 1992). The program starts no later than Grade 1 and continues to Grade 12 and is characterized by full French instruction from the start of school through Grade 2. French instruction, with the introduction of English language arts (in Grade 3), drops to about $80 \%$ and then continues a slow but steady decline till the end of high school (PISA, 2000). Immersion teachers in the primary grades have been shown to utilize teaching techniques such as teaching in both languages, that make the acquisition of a language easier and the retention of a second language much more effective than bilingual teachers in higher grades (Taylor, 1992). The registration decision of the early immersion program is mostly made by the parents and therefore reflects the personal goals of parents for their children.

\subsubsection{Middle French Immersion}

Middle French Immersion starts with a level of $80 \%$ French instruction at Grade 3, with the remaining $20 \%$ of instruction in the English language (Peirce\& And, 1993). This immersion is a mix of Early and Late Immersion program. Students in a middle immersion program tend to outperform students in late immersion program. Testing regularly indicates this to be the case for the spontaneous and oral fluency of using language (Dicks, 1995; Peirce \& And, 1993). Therefore, students in this program can be eligible in the early immersion program for writing and reading skills and more analytical language testing. Thus, the effectiveness of this program has been reported to be somewhere between Early and Late French programs (PISA, 2000).

\subsubsection{Late French Immersion}

Late French Immersion programs start at Grade 7 and continue to Grade 12 (Cummins, n.d., 1982). Instruction in core subjects such as social studies, science, and math are delivered completely in French apart from English and language arts. On the other hand, due to the assortment of course options taught in English, "the amount of French instruction tends to decrease in the higher grades" (PISA, 2000, p. 34). 


\subsection{Support for Immersion Programs}

French immersion programs receive a great deal of support because they promote bilingualism in the country. Bilingualism has been found to have positive impacts on cognitive skills such as learning a language and does not hinder performance in either language (Genessee \& Gandara, 1999; Cummins, 1982). French Immersion program students, particularly early immersion participants, achieve levels of written and oral comprehension very much like those of native French speakers. French immersion students are perfectly capable of participating in a program at a French university, in a French community, or even work in a French workplace by the end of their education (Dicks, 1995).

Early Immersion students in the primary grades may show a bit of a lag in their English skills, particularly in areas of grammar, such as capitalization; however, this lag quickly disappears by the introduction of language arts studies in Grade 3 (Taylor, 1992). According to Roy (2008), no noticeable differences exist in the English proficiency of students between non-French immersion students and French immersion students until Grade 5. Indeed, French immersion students continually have surpassed their counterparts on English reading assessments (PISA, 2000).

\subsection{Teachers' Proficiency within French Immersion Programs}

Since the inception of language immersion programs, immersion teachers have played a key role in promoting bilingualism in Canada. Teacher qualification in French-immersion programs in most Canadian provinces is an important concern (McEachern, 2002). A lack of qualified teachers in Canadian provinces, where the demand for French-immersion services has been increasing, has meant that many districts were unable to provide space for all children who desired to be involved in French-immersion programs. The lack of bilingual educators at the secondary level, where teachers must specialize in their content area and their French-language abilities, has been acute (Hermans-Nymark, 2013; McEachern, 2002). The French teachers are usually fluent in French as their native language, and therefore not all the pre-service teachers follow their preparation of French program in Canada. That is why "for all FSL (French as a second language) teachers, a special qualification certificate in FSL whether teaching in core or immersion programs is a requirement" (McEachern, 2002, p. 7).

Ministries of Education and universities have been made more conscious of the unique professional development needs of French immersion teachers (Day \& Shapson, 1996). They have been pressured to increase their support and obligation to provide professional development activities for immersion teachers. Courses and opportunities considered specifically for teaching subject matter in a second language are particularly necessary for immersion teachers in the Canadian bilingual education system (Sanders, 1992).

\subsection{Summary}

Most Canadians (81\%) strongly support bilingual education and bilingualism and willingly desire to remain as a bilingual country (CROP, 2006). The rate of French-English bilingualism outside of Quebec (57\%) that has been reported is not high enough for students 
to learn both languages; therefore, the rate of French-English bilingualism outside of Quebec, according to parents, should be higher (CROP, 2006). Most Canadians (86\%), according to the Centre for Research and Information on Canada (2002), have articulated the importance of learning a second language for their children. Likewise, 66\% of Canadians (aged 11-29) believe that high-school graduates should know both French and English for their future careers.

With more potential learners and speakers than ever before, the innovative legal approach to education in Canada has helped develop bilingualism (Roy \& Galiev, 2011; Cummins, 2001). Currently, many of new generation speak both in English and French, are well educated, and completely literate in Canada. A growing new wave of printed materials in French and English has helped according to Roy and Galiev (2011). The use of French bilingually in church, in printed materials, and in elementary and secondary educational environments has increased continuously. The existence of the French language and culture has now been ensured at least well into the $21^{\text {st }}$ century, and French is being used in zones in which it has never been used in before, such as school or university positions, audiovisual materials, administration, and computer software (Cummins, 2000). This indicates the pervasiveness of bilingualism in the academy and public in Canada.

\section{Discussion and Conclusion}

A comparison of the situation of minority languages in Turkey with Canada and Spain offers many lessons. Currently, in Turkey, there is not any educational model to handle the non-Turkish languages. The structures of bilingual education programs in Spain and Canada used in education for minority groups can be debated in consideration of their historical and political contexts. The purpose of this discussion is to establish the benefits and shortcomings of these bilingual education programs and the suitability of their models for minority groups living in Turkey. To provide an efficient education system, the differing needs of various areas should be considered. This can be demonstrated in examples drawn from Canada's consideration of the French language and Spain's consideration of the Basque language.

Implementing a bilingual program following either the Spanish and Canadian models could enable learners to develop better attitudes towards schools in Turkey. Adapting a bilingual program could influence positively the accomplishment of students and help them gain self-confidence (Cummins, 2003). Moreover, students who have an efficient and expanding education are better able to engage in intercultural communication, which, in turn, may increase peace within the Turkish society (Aydin, \& Ozfidan, 2014; Ozfidan, Burlbaw, \& Kuo, 2016). That is in no small measure because they can have meaningful dialogues with other people of diverse cultures who speak different languages (Cummins, 1991). Such effectiveness can be seen in both the Canadian French and Spanish Basque bilingual education examples. Therefore, the successful aspects of these bilingual education programs should be considered for minority groups who cannot speak the Turkish language in Turkey.

For the education of minority students, a bilingual educational model in Turkey should be improved. Crucial work parallel to this development should consider the implementation of educational measures such as the being currently employed by Spain and Canada's bilingual 
education programs. Because of changing conditions and needs, experts should revise the Turkish education system while considering the bilingual aspects.

However, to overcome these problems, Turkey should choose the best from the Spanish and Canadian models, while developing and improving their own model. During the development of this model, the needs of students, parents, and teachers, as seen in Spain and Canada, should be considered. When creating policies in Turkey, challenges such as the lack of proficiency in teaching, funding, the use of a standard variety of the language, the development of teaching materials and appropriate teaching methods such as occurs in the Canadian and Spanish models should be emulated so as not encounter the problems Turkish education has faced before. For the development of a Turkish model of bilingual education, exploring the effective bilingual programs of these two countries would provide inspiration.

To implement an educational system incorporating the best of the Canadian and Spanish models, fundamental work should be performed. Examining the Basque Country's efficient bilingual models and the Canadian French immersion programs in Canada could provide guidance for the development of bilingual education programs in Turkey. For instance, the Basque bilingual education and Canadian French immersion program both have three different models. These models are options for parents, and they can choose an appropriate model for their children. For example, in Basque bilingual education program, students, in model A, learn in Spanish only. In model B, students learn in Basque only. In model D, students learn in both Basque and Spanish.

The Turkish government should also consider a model such as Spain and Canada currently use. The Turkish government can also establish three different models $(1,2,3)$ as Spain and Canada have done. In Model 1, the minority language would be taught for three to five hours a week as a second language, and almost all subjects would be taught in Turkish. Model 2 would be optimal for both Turkish and minority speakers who want to be bilingual in both languages. This model's purpose would be to help students acquire fluency in both languages. In Model 3, the minority language would be the primary language of instruction for four to five hours a week, and Turkish would be taught as a subject.

Bilingual education in both Spain and Canada indicated that teaching in both Spanish and French is undoubtedly related to human rights. Speaking a mother tongue in educational, social, and governmental environments is considered a human right (UNESCO, 2003; May, 2005). One important problem to solve with respect to the language issue of minority groups is educational rights (Ozfidan, Machtmes, \& Demir, 2014). In doing so, the Turkish government should consider bilingual education programs such as Basque bilingual education in Spain and French Immersion program in Canada. For a potential bilingual education program in Turkey, the government should consider the needs and demands of minority groups in Turkey. The government should also consider protecting and developing the mother tongue because being bilingual offers many benefits, such as preserving cultural and ethnic identity, linguistic knowledge, and helping to socialize people to participate in the community. In spite of governmental concern about the development of separatist mentality if minority languages are recognized and widely taught and accepted language, similar concerns in 


\section{Macrothink}

Canada and Spain have not been borne out and Quebec and BAC remain a part of those nations.

\section{References}

Arzamendi, J., \& Genesee, F. (1997). Reflections on immersion education in the Basque country. In K. Johnson \& M. Swain (Eds.), Immersion Education: International Perspectives (pp. 151-166). Cambridge: Cambridge University Press. https://doi.org/10.1017/CBO978113 9524667.014

Aydin, H., \& Ozfidan, B. (2014). Perceptions on mother tongue based multicultural and bilingual education in Turkey. Multicultural Education Review (MER), 6(1), 51-78.

Blanton, C. K. (2004). Strange career of bilingual education in Texas, 1836-1981. Texas A\&M University Press.

Bretón, N., \& Ruiz, P. (2008). Bilingual education in Navarre: Achievements and challenges. Language, Culture \& Curriculum, 21(1), 21-38. https://doi.org/10.2167/lcc340.0

Canadian Council on Learning (CCL). (2007). French-Immersion education in Canada. Retrieved from http://www.ccl-cca.ca/pdfs/LessonsInLearning/May-17-07-French-immersion. pdf

Cenoz, J. (2008). Achievements and Challenges in Bilingual and Multilingual Education in the Basque Country. AILA Review, 21, 13-30.

Cenoz, J. (2012). Bilingual Educational Policy in Higher Education in the Basque Country. Language, Culture and Curriculum, 25(1), 41-55. https://doi.org/10.1080/07908318.2011. 653057

Centre for Research and Information on Canada. (2002). Portraits of Canada 2001.

Cooke, M. (2009). A Collision of Culture, Values, and Education Policy: Scrapping Early French Immersion in New Brunswick. Education Canada, 49(2), 46-50.

CROP. (2006). Les Canadiens et le bilinguisme: Rapport final. Présenté à la Société Radio-Canada, Recherche, Grille et Diffusion.

Cummins, J. (1982). Through the Looking Glass: What Really Happens in an Immersion Classroom. Interchange on Educational Policy, 13(2), 40-44. https://doi.org/10.1007/ BF01807900

Cummins, J. (1991). Language development and academic learning. In L. Malave \& G. Duquette (Eds.), Language, culture and cognition. Clevedon, UK: Multilingual Matters.

Cummins, J. (2000). Language, power and pedagogy: Bilingual children in the crossfire. Clevedon, Multilingual Matters.

Cummins, J. (2001). Bilingual Children's Mother Tongue: Why is it important for education. Sprogforum, 19, 15-20. 
Cummins, J. (n.d.). Immersion education for the millennium: What we have learned from 30 years of research on second language immersion. Retrieved from http://www.iteachilearn. com/cummins/immersion2000.html

Day, E., \& Shapson, S. M. (1996). A national survey: French immersion teachers' preparation and their professional development needs. Canadian Modern Language Review, 52, 248-270.

De La Trinidad, M. (2015). Mexican Americans and the push for culturally relevant education: The bilingual education movement in Tucson, 1958-1969. History of Education, 44(3), 316-338. https://doi.org/10.1080/0046760X.2014.1002015

Dicks, J. (1995). A comparative study of the acquisition of French verb tense and aspect in early, middle, and late immersion. Quebec: Centre International de Recherche en Aménagement Linguistique.

Etxeberria, F. S. (2006). Attitudes towards Language Learning in Different Linguistic Models of the Basque Autonomous Community. In O. Garcia, T. Skutnabb-Kangas, \& E. Torres-Guzman (Eds.), Imagining Multilingual School: Language in Education and Glocalization (pp. 111-133). England: Multilingual Matters.

Everling, K. M. (2009). Lau vs. Nichols 40 years later-Where are we now? A study of philosophical, political, cultural and societal issues impacting bilingual education in the early 21st century (Doctoral dissertation, Texas A\&M University, USA). Retrieved from http://hdl.handle.net/1969.1/ETD-TAMU-2009-12-7391

Gándara, P. (2015). Rethinking Bilingual Instruction. Educational Leadership, 72(6), 60.

Gardner, N. (2000). Basque in education in the Basque Autonomous Community. Vitoria-Gasteiz: Basque Government. Retrieved June 21, 2012, from http://www.hezkuntza. ejgv.euskadi.net/r43573/eu/contenidos/informacion/dia6/en_2027/adjuntos/Basque_in_Educa tion_i.pdf

Genessee, F., \& Gándara, P. (1999). Bilingual education programs: A cross-national perspective. Journal of Social Issues, 55(4), 665-685. https://doi.org/10.1111/0022-4537. 00141

Government of Canada. (2003). The next act: New momentum for Canada's linguistic duality: The action plan for official languages. Retrieved from http:/www.cpfnb.com/articles/ ActionPlan_e.pdf

Haddican, B. (2007). Suburbanization and Language Change in Basque. Language in Society, 36, 677-706. https://doi.org/10.1017/S0047404507070923

Hermans-Nymark, L. (2013). The Path to Bilingualism: The Common European Framework for Languages in Canada. Education Canada, 53(1).

Horn-Marsh, P. M., \& Horn-Marsh, K. L. (2009). Bilingual Students Publish Works in ASL and English. Odyssey: New Directions in Deaf Education, 10(1), 12-17.

Intxausti, N., Etxeberria, F., \& Joaristi, L. (2013). Involvement of Immigrant Parents in Their 
Children's Schooling in a Bilingual Educational Context: The Basque Case (Spain). International Journal of Educational Research, 59, 35-48. https://doi.org/10.1016/j.ijer. 2013.02.006

Kim, Y. K., Hutchison, L. A., \& Winsler, A. (2015). Bilingual education in the United States: An historical overview and examination of two-way immersion. Educational Review, 67(2), 236-252. https://doi.org/10.1080/00131911.2013.865593

Laborda, J. G. (1997). Bilingual education in Canada: Description and evaluation of the immersion programme. Madrid: ESIC Marketing College.

Lambert, W. S., \& Tucker, G. R. (1976). Tu, vous, usted: A social-psvchological study of address patterns. City, MA: Newbury House.

Lasagabaster, D. (2001). Bilingualism, Immersion Programmes and Language Learning in the Basque Country. Journal of Multilingual and Multicultural Development, 22(5), 401-25. https://doi.org/10.1080/01434630108666443

Mady, C. (2012). Official Language Bilingualism to the Exclusion of Multilingualism: Immigrant Student Perspectives on French as a Second Official Language in "English-Dominant" Canada. Language and Intercultural Communication, 12(1), 74-89. https://doi.org/10.1080/14708477.2011.592193

Mady, C. (2013). Moving towards Inclusive French as a Second Official Language Education in Canada. International Journal of Inclusive Education, 17(1), 47-59. https://doi.org/ $10.1080 / 13603116.2011 .580463$

Mady, C. (2014). Learning French as a Second Official Language in Canada: Comparing Monolingual and Bilingual Students at Grade 6. International Journal of Bilingual Education and Bilingualism, 17(3), 330-344. https://doi.org/10.1080/13670050.2013.767778

McEachern, W. (2002). Teaching and learning in bilingual countries: The example of Belgium and Canada. Education, 123(1), 103.

Ngai, P. B. (2002). Bilingual Education for All: A Benefits Model for Small Towns. Bilingual Research Journal, 26(2), 269-94. https://doi.org/10.1080/15235882.2002.10668711

Ozfidan, B., \& Burlbaw, L. M. (2016). Perceptions of Bilingual Education Model in Spain: How to Implement a Bilingual Education Model in Turkey. Journal of Ethnic and Cultural Studies, 3(1), 49-58.

Ozfidan, B., Burlbaw, L., \& Kuo, L. J. (2016). Perceptions of an Anticipated Bilingual Education Program in Turkey. International Education Studies, 9(10), 174. https://doi.org/ 10.5539/ies.v9n10p174

Ozfidan, B., Machtmes, K., \& Demir, H. (2014). Socio-cultural Factors in Second Language Learning: A Case Study of Adventurous Adult Language Learners. European Journal of Education Research, 3(4), 185-191. https://doi.org/10.12973/eu-jer.3.4.185

Parisot, A., \& Rinfret, J. (2012). Recognition of Langue des Signes Quebecoise in Eastern 
Canada. Sign Language Studies, 12(4), 583-601. https://doi.org/10.1353/sls.2012.0013

Peirce, B. N., \& And, O. (1993). Self-Assessment in Two French Immersion Programs. Applied Linguistics, 14(1), 25-42. https://doi.org/10.1093/applin/14.1.25

Peleato, I. V. (2013). Bilingual Education Policies and Models in the Treatment of Linguistic Diversity in the United States. Revista de Educación, 360, 685-696.

Program for International Student Assessment (PISA). (2000). Overview and history of the Canadian program. Retrieved from http://sitemaker.umich.edu/356.hess/overview_of_the canadian_program

Ricento, T. (2013). The consequences of official bilingualism on the status and perception of non-official languages in Canada. Journal of Multilingual \& Multicultural Development, 34(5), 475-489. https://doi.org/10.1080/01434632.2013.783034

Roy, S. (2008). French Immersion Studies: From Second-Language Acquisition (SLA) to Social Issues. Alberta Journal of Educational Research, 54(4), 396-406.

Roy, S., \& Galiev, A. (2011). Discourses on bilingualism in Canadian French immersion programs. Canadian Modern Language Review/La Revue Canadienne Des Langues Vivantes, 67(3), 351-376. https://doi.org/10.3138/cmlr.67.3.351

San Miguel, G. (2004). Contested Policy: The Rise and Fall of Federal Bilingual Education in the United States, 1960-2001. Denton, Tex: University of North Texas Press.

Sanders, M. (1992). Language learning in French immersion classrooms in the transition year: Information for language learning teachers. Alberta Department of Education.

Sierra, J. (2008). Assessment of Bilingual Education in the Basque Country. Language, Culture and Curriculum, 21(1), 39-47. https://doi.org/10.2167/lcc341.0

Taylor, S. (1992). Victor: A Case Study of a Cantonese Child in Early French Immersion. Canadian Modern Language Review, 48(4), 736-59.

Urla, J. (2009). Ethnic Protest and Social Planning: A Look at Basque Language Revival. Cultural Anthropology, 3, 379-394. https://doi.org/10.1525/can.1988.3.4.02a00030

Valadez, C., Etxeberria, F., \& Intxausti, N. (2015). Language Revitalization and the Normalization of Basque: A Study of Teacher Perceptions and Expectations in the Basque Country. Current Issues In Language Planning, 16(1-2), 60-79. https://doi.org/10.1080/ 14664208.2014.947019

Zalbide, M., \& Cenoz, J. (2008). Bilingual education in the Basque Autonomous Community: Achievements and challenges. Language, Culture and Curriculum, 21(1), 5-20. https://doi.org/10.2167/lec339.0

Zuazo, K. (1995). The Basque Country and the Basque language: An overview of the external history of the Basque language. In J. I. Hualde, J. Lakarra \& R. L. Trask (Eds.), Towards a History of the Basque Language (pp. 5-30). Philadelphia: John Benjamins. 


\section{Copyright Disclaimer}

Copyright for this article is retained by the author(s), with first publication rights granted to the journal.

This is an open-access article distributed under the terms and conditions of the Creative Commons Attribution license (http://creativecommons.org/licenses/by/3.0/). 